\title{
REFUGEE PARTICIPATION REVISITED: THE CONTRIBUTIONS OF REFUGEES TO EARLY INTERNATIONAL REFUGEE LAW AND POLICY
}

\author{
TRISTAN HARLEY*
}

\begin{abstract}
This article challenges the assumption that until relatively recently refugees or persons with lived refugee experience have not been involved in the development of international refugee law and policy. By drawing on primary source material - including the preparatory work for international legal instruments such as the 1933 Convention Relating to the International Status of Refugees and the 1951 Convention Relating to the Status of Refugees, along with the operational work of the League of Nations, the International Refugee Organization and the early years of UNHCR - this article argues that refugees and persons with lived refugee experience exercised significant influence and thought-leadership in the development of international refugee law and policy making during the foundational years between 1921 and 1955. These contributions to the development of international refugee law and policy are significant because they not only reorient our understanding of the ways in which international law and policy pertaining to refugees has been developed and negotiated to date, but also because they provide a practical example of how refugees can more meaningfully be included in the creation of laws and policies that affect them going forward.
\end{abstract}

\footnotetext{
* PhD Candidate, Kaldor Centre for International Refugee Law, University of New South Wales. This paper was commissioned by UNHCR. It reflects the personal views of the author, which may not necessarily be shared by UNHCR, and UNHCR may not be held responsible for any use that may be made of the information contained therein. The author would like to thank Guy S Goodwin-Gill, Claire Higgins, Ninette Kelley, Emma Dunlop, Brian Barbour and Natasha Yacoub for their generous comments on earlier drafts of this paper.
} 


\section{INTRODUCTION}

In recent years, numerous initiatives have been developed with the aim of enhancing the meaningful participation of refugees in the development and implementation of international refugee law and policy. Refugee-led initiatives such as the Global Summit of Refugees and the Global Refugee-led Network have sought to create a space for refugees to engage directly with States, international organisations, civil society and others in the development of laws and policies that affect them. ${ }^{1}$ Further, new legal instruments, particularly the 2016 New York Declaration for Refugees and Migrants ${ }^{2}$ and the 2018 Global Compact on Refugees, ${ }^{3}$ have also recognised the value of meaningful participation and made commitments, albeit non-binding, from States towards enabling the participation of refugees in designated responses to refugees and displacement.

These initiatives represent a significant shift in thinking about the participation of refugees in law, policy making and governance in the modern international refugee regime. Under international law, there is no binding obligation explicitly mandating the participation of refugees in decisions that affect them, so the development of these participatory commitments and initiatives are noteworthy. ${ }^{4}$ These initiatives respond to moral claims that refugees should have a say in decisions that affect their rights, ${ }^{5}$ as well as instrumental

\footnotetext{
${ }^{1}$ See Global Summit of Refugees, Policy Discussion and Outcomes Paper, Geneva, Aug. 2018, available at: https://www.globalrefugeelednetwork.org/wp-content/uploads/2019/11/GSOR-Outcome-and-Policy-Papers.pdf (last visited 1 Sep. 2020) 1, 5; also, Global Refugee-led Network, Meaningful Refugee Participation as Transformative Leadership: Guidelines for Concrete Action, Dec. 2019, available at: https://asylumaccess.org/wp-content/uploads/2019/12/Meaningful-Refugee-Participation-Guidelines_Web.pdf (last visited 1 Sep. 2020).

${ }^{2}$ New York Declaration for Refugees and Migrants, $71^{\text {st }}$ sess., Agenda items 13 and 117, UN Doc A/RES/71/1, 3 Oct. 2016 ('New York Declaration').

${ }^{3}$ Global Compact on Refugees, $73^{\text {rd }}$ sess., Supp No 12, UN DOC A/73/12 (Part II), 2 Aug. 2018 ('Global Compact on Refugees').

${ }^{4}$ For further analysis of the legal scope and nature of refugee participation and consultation in international law, see T. Harley and H. Hobbs, "The Meaningful Participation of Refugees in Decision Making Processes: Questions of Law and Policy", International Journal of Refugee Law, 32(2), 2020, 200-226.

${ }^{5}$ Legal and political philosopher Jeremy Waldron, for example, has described this moral claim as the right of everyone to "have his or her voice reckoned with and counted", regardless of formal legal categories of alienage and citizenship: see J. Waldron, Dignity, Rank and Rights, Oxford, Oxford University Press, 2012, 35. Among refugee advocates, this claim is commonly captured in the use of the expression "Nothing about us, without us!": see, for example, S. Mustafa, "Nothing About Us Without Us: Why Refugee Inclusion is Long Overdue", NewsDeeply, 20 Jun. 2018 , available at https://www.newsdeeply.com/refugees/community/2018/06/20/nothingabout-us-without-us-why-refugee-inclusion-is-long-overdue (last visited 1 Sep. 2020); also, Refugee Council of Australia and Independent Diplomat, Nothing about us without us: Getting serious about refugee selfrepresentation, Sydney, Jul. 2017, available at: https://www.refugeecouncil.org.au/wp-
} 
rationales that increased refugee participation will improve policy effectiveness. ${ }^{6}$ However, for these commitments to be effectively realised, there is a need to consider further how refugees can be more meaningfully included in decision-making processes that affect them. Part of this consideration includes providing conceptual clarity in relation to understandings of participation, decision-making and governance across all facets of the international refugee regime. Beyond this, there is also a need to examine the historical record to see what can be learnt from past attempts to include refugees in the design and implementation of international refugee law and policy.

In contemporary discourses, calls for greater participation of refugees in international law and policy making are often made with the implicit, and at times explicit, assumption that this type of participation has not occurred previously. For example, following the conclusion of the first ever Global Refugee Forum in December 2019, ${ }^{7}$ the United Nations High Commissioner for Refugees (UNHCR) reported that among the 3000 participants to attend the event, "crucially, 70 refugees participated from 22 countries of origin and 30 host countries". UNHCR emphasised that "the pivotal role of refugees in both preparing for and participating in the forum has set an important precedent that we will build upon for the future". ${ }^{8}$ Similarly, many civil society organisations and refugee-led organisations advocating for increased involvement of refugees in law and policy making likewise have not raised attention to the history of refugee involvement in the creation of early international refugee law, suggesting that this history is either unknown, forgotten or deprioritised.

This article seeks to challenge the assumption that until relatively recently refugees or persons with lived refugee experience have not been involved in the development of international refugee law and policy. By drawing on primary source material - including the preparatory work for international legal instruments such as the 1933 Convention Relating to

content/uploads/2018/12/Geneva-2017_Nothing-About-Us-Without-Us-Report_Final-Report.pdf (last visited 1 Sep. 2020).

${ }^{6}$ See, for example, UNHCR, The UNHCR Tool for Participatory Assessment in Operations, Geneva, May 2006, available at: https://www.refworld.org/docid/462df4232.html (last visited 1 Sep. 2020) 1; also, Global Compact on Refugees, para 34 (discussed below).

${ }^{7}$ The Global Refugee Forum is a periodic forum convened for all United Nations Member States, along with relevant stakeholders, to announce and monitor pledges and contributions to the objectives of the Global Compact on Refugees. The first Global Refugee Forum took place in Dec. 2019. Subsequent forums are proposed to take place every four years. See Global Compact on Refugees, paras. 17-19.

${ }^{8}$ UNHCR, Summary of participation and pledges at the Global Refugee Forum, Geneva, Jan. 2020, available at: https://www.unhcr.org/5e20790e4 (last visited 1 Sep. 2020). It is understood that during the three-day forum, persons with lived refugee experience featured on each panel convened. 
the International Status of Refugees (1933 Convention) $)^{9}$ and the 1951 Convention Relating to the Status of Refugees (1951 Convention), ${ }^{10}$ along with the operational work of the League of Nations, the International Refugee Organization and the early years of UNHCR - this article argues that persons with lived refugee experience exercised significant influence and thoughtleadership in the development of international refugee law and policy making during the foundational years between 1921 and 1955. ${ }^{11}$

While it is important not to overstate this influence - refugees as a categorised group held no formal decision-making power, and negotiations on matters of international law were, and still are, largely inter-State affairs - persons with lived refugee experience nevertheless actively drew on their personal experiences and expertise in law and policy to inform the drafting and deliberation of these international instruments, and were substantively involved in the responses coordinated by international organisations such as the League of Nations and UNHCR. During this period, persons with lived refugee experience not only held senior leadership positions within each of these international organisations, but these organisations regularly consulted and collaborated with organisations which, utilising contemporary terminology, would now be labelled refugee-led organisations. ${ }^{12}$ Even the initial idea of

\footnotetext{
${ }^{9}$ Convention Relating to the International Status of Refugees, 159 LNTS 3663, 28 Oct. 1933 (entry into force: 13 Jun. 1935) ('1933 Refugee Convention').

${ }^{10}$ Convention Relating to the Status of Refugees, 189 UNTS 150, 28 Jul. 1951 (entry into force: 22 Apr. 1954) ('1951 Refugee Convention').

${ }^{11}$ Although this paper interrogates periods of international refugee law prior to 1951, when referring to a 'refugee' this paper adopts as a starting point the legal definition contained in the 1951 Refugee Convention. This approach has been taken as the 1951 Refugee Convention definition is the basis for most contemporary understandings of international refugee law and policy making. Under Article 1A(2) of the 1951 Refugee Convention, as modified by the 1967 Protocol Relating to the Status of Refugees, a refugee is defined as someone who is outside their country of origin and unable or unwilling to return or to avail themselves of that country's protection owing to a well-founded fear of being persecuted for reasons of race, religion, nationality, membership of a particular social group or political opinion. The term 'persons with lived refugee experience' in this paper refers to individuals who would have met the 1951 Convention definition of a refugee previously (had it been applied at the time), but for some reason no longer have a well-founded fear of persecution for one of the five grounds. The 1967 Protocol can be found at Protocol Relating to the Status of Refugees, 606 UNTS 267, 31 Jan. 1967 (entry into force: 4 Oct. 1967) ('1967 Protocol').

${ }^{12}$ At the time, these organisations were generally referred to as either private organisations or voluntary organisations, which included civil society organisations as well. Although there is no commonly accepted definition (legal or otherwise) of what constitutes a 'refugee-led organisation', this paper interprets the term to refer to non-governmental, membership-based organisations that are led and controlled by refugees for the purpose of collectively acting in relation to a common interest pertaining to refugees. These organisations may operate as individual organisations, or alternatively as coalitions or umbrella organisations. Importantly, organisations of refugees should be distinguished from organisations for refugees. While the former are led and controlled by refugees, the latter are normally civil-society organisations which provide services to refugees and/or advocate on their behalf. This definition of refugee led-organisations borrows from the definition of representative organisations of persons with disabilities which has been developed by the Special Rapporteur on the rights of persons with disabilities. See UN Human Rights Council, Report of the Special Rapporteur on the rights of persons with disabilities, $31^{\text {st }}$ sess., UN Doc A/HRC/31/62, 12 Jan. 2016, paras. 36-38.
} 
creating a binding international law treaty to deal specifically with refugees was first proposed by a refugee in 1927, writing on behalf of a refugee-led organisation. ${ }^{13}$

Surprisingly, these contributions have been largely overlooked in academic texts until now. Most legal analysis of the development of international refugee law has tended to focus on the role of States as the key architects in legal development. This is consistent with positivist understandings of international law, which gives primacy to those actors with law-making powers, namely States. Within the paradigm of modern legal positivism, personal experiences of individual participants, especially those experiences that may evoke emotions such as fear and trauma, are suppressed because they are seen as undermining law's claims to legitimacy through its associations with objectivity and neutrality. ${ }^{14}$ The rules of treaty interpretation under international law further reinforce this statist focus, as the contributions of non-State actors are given virtually no legal weight in identifying how a treaty's meaning is to be interpreted in international law, unless these contributions are reflected in the final text of the treaty or are formally recorded in the official preparatory works. ${ }^{15}$

Further, within the disciplines of history and anthropology, most scholars looking at the contributions of refugees have more recently tended to focus on bottom-up participatory initiatives involving refugees, rather than top-down treaty-making processes. ${ }^{16}$ In the few studies where there has been a focus on individuals in the early history of international refugee law, scholars have either emphasised the professional diplomatic experience of these persons as being central to their leadership in these organisations, ${ }^{17}$ or alternatively have emphasised

\footnotetext{
${ }^{13}$ This proposal is discussed in further detail below.

${ }^{14}$ For more on the exclusion of emotion from law and the conceptual underpinnings of modern legal positivism, see R. Grossi, Looking for Love in the Legal Discourse of Marriage, Canberra, Australian National University Press, 2014, 3-9; also, R. Grossi, "Law, emotion and the objectivity debate", Griffith Law Review, 28(1), 2019, $23-36$.

${ }^{15}$ Under article 31 of the Vienna Convention on the Law of the Treaties (VCLT), "a treaty shall be interpreted in good faith in accordance with the ordinary meaning to be given to the terms of the treaty in their context and in light of its object and purpose". Article 32 of the VCLT provides that "recourse may be had to supplementary means of interpretation, including the preparatory work of the treaty and the circumstances of its conclusion, in order to confirm the meaning resulting from the application of article 31 , or to determine the meaning when the interpretation according to article 31: (a) leaves the meaning ambiguous or obscure; or (b) leads to a result which is manifestly absurd or unreasonable": Vienna Convention on the Law of Treaties, 1155 UNTS 331, 23 May 1969 (entry into force: 27 Jan. 1980).

${ }^{16}$ For further analysis of refugee and forced migration history 'from below', see J. Elie, "Histories of Refugee and Forced Migration Studies", in E. Fiddian-Qasmiyeh et al (eds.), The Oxford Handbook of Refugee and Forced Migration Studies, Oxford, Oxford University Press, 2014, 23-35, 30-31.

${ }^{17}$ For example, writing about the origins of UNHCR, Gil Loescher notes that "The role of individuals in UNHCR's early history and the leadership provided from the Office's first four high commissioners were essential to its success and influence during this period. All of these leaders had a UN political background, which increased the likelihood that they would be successful, particularly since the Office relied on the support of the UN
} 
the Jewish roots of these intellectual traditions. ${ }^{18}$ Refugee experience of participants is on occasions acknowledged, but there have been few attempts to reflect on the significance of this.

Beyond this, this oversight may also be partly due to a broader trend that has largely rendered invisible the contributions of refugees to their own protection. This is in part due to the fact that the most readily accessible (and actively published) sources for analysis are those which emphasise the contributions of States, international organisations and civil society organisations. However, it is also due to a culturally-developed phenomenon of viewing refugees as 'victims' or passive, vulnerable subjects, rather than as significant agents of change. ${ }^{19}$ This phenomenon has emerged despite many of the key thinkers of international law and refugee protection having lived experienced of forced displacement, such as Hugo Grotius and Hannah Arendt. Some academics are beginning to grapple with this oversight. However, so far much of the research has focused on the contributions of refugees to programme and service delivery, rather than their involvement in international law and policy reform. ${ }^{20}$

The contributions of refugees to the creation of international law are significant because they not only reorient our understanding of the ways in which international law pertaining to refugees has been developed and negotiated to date, but also because they provide a practical example of how refugees can more meaningfully be included in the creation of laws and policies that affect them going forward, particularly at the level of international governance. In the 2018 Global Compact on Refugees, there is recognition that "responses are most effective when they actively and meaningfully engage those they are intended to protect and assist", however the instrument provides very little guidance as to how this engagement should be pursued. The Compact simply states that "relevant actors will, wherever possible, continue to

secretaries-general and the UN General Assembly to expand its operations and authority": G. Loescher, "UNHCR's Origins and Early History: Agency, Influence, and Power in Global Refugee Policy", Refuge, 33(1), 2017, 77-86, 84.

${ }^{18}$ See, for example, G. Ben-Nun, "The Israeli Roots of Article 3 and Article 6 of the 1951 Refugee Convention”, Journal of Refugee Studies, 27(1), 2013, 101-125; also, O. Kaplan-Feuereisen and R. Mann, "At the Service of the Jewish Nation: Jacob Robinson and International Law", Osteuropa: Impulses for Europe: Tradition and Modernity in East European Jewry, 58(8/10), 2008, 157-170.

${ }^{19}$ P. Gatrell, "Refugees - What's Wrong with History?", Journal of Refugee Studies, 30(2), 2017, 170-189, 175; also, N. Sigona, "The Politics of Refugee Voices: Representations, Narrative, and Memories", in E. FiddianQasmiyeh et al (eds.), The Oxford Handbook of Refugee and Forced Migration Studies, Oxford, Oxford University Press, 2014, 369-382; also, N. Omata, "Unwelcome Participation, Undesirable Agency? Paradoxes of De-Politicisation in a Refugee Camp”, Refugee Survey Quarterly, 36(3), 2017, 108-131, 113.

${ }^{20}$ See, for example, K. Pincock, A. Betts and E. Easton-Calabria, The Global Governed?: Refugees as Providers of Protection and Assistance, Oxford, Oxford University Press, 2020; also D. Williams, A bridge to life in the UK: Refugee-led community organisations and their role in integration, London, UK Refugee Council, Oct. 2018, available at: https://www.refugeecouncil.org.uk/information/resources/a-bridge-to-life-in-the-uk-refugee-ledcommunity-organisations-and-their-role-in-integration/ (last visited 1 Sep. 2020). 
develop and support consultative processes that enable refugees and host community members to assist in designing appropriate, accessible and inclusive responses". ${ }^{21}$ It is hoped that this case study will provide insights into some of the possibilities and practicalities of more meaningful participation of refugees in the development of international law and policy, albeit recognising that the international refugee regime has grown and changed considerably since its origins.

This article is divided into four main parts. First, the article considers some of the contributions of refugees in the preliminary responses to refugee displacement in the years between the two world wars, and the development of the first binding international convention relating to refugees - the 1933 Convention. Second, the article analyses some of the contributions of persons with lived refugee experience to the drafting and development of the 1951 Refugee Convention. Third, the article examines the contributions of Gerrit Jan Van Heuven Goedhart - the first High Commissioner of UNHCR, and a leader with lived refugee experience - to the foundational years of UNHCR. Finally, the article provides commentary on the significance of these contributions and examines the relevance of these contributions for contemporary understandings of participatory refugee initiatives.

\section{CONTRIBUTIONS OF REFUGEES TO INTERNATIONAL REFUGEE LAW AND POLICY IN THE INTERWAR YEARS}

Contrary to the belief that refugee voices have largely been ignored in international law and policy making until very recently, the historical record from the early international responses to refugees in the first half of the twentieth century suggests that refugees contributed to the development of international refugee law and policy more substantively than previously considered. In some ways, this approach to law and policy making occurred as a matter of practical necessity, rather than as a result of deliberate institutional design. With the exception of some early humanitarian organisations already in existence such as the American Red Cross, many international non-governmental organisations mandated to provide protection to refugees had not yet been established at that time, and refugees, including their constituent groups,

\footnotetext{
${ }^{21}$ Global Compact of Refugees, para. 34.
} 
largely filled the role as first responders. ${ }^{22}$ States and international organisations similarly relied on refugees' knowledge and expertise to identify needs and assist with the design and implementation of solutions.

In 1921, when the newly established League of Nations recognised that the issue of refugees demanded a coordinated international response and appointed the Norwegian explorer Fritjof Nansen as first High Commissioner for Russian Refugees, Nansen quickly recognised the need to consult with refugee communities and took action to establish an advisory committee, known as the Advisory Committee of Private Organisations, to inform the trajectory of the League of Nations' responses to Russian refugees. This committee consisted of both newly established civil society organisations - organisations that sought to provide services to refugees and/or advocate on their behalf - as well as organisations led and controlled by refugees. ${ }^{23}$ Within a year, this advisory committee was already regularly reporting to the League of Nations on some of the practical needs of refugees across different European nations. At the time, this advice focused heavily on the provision of work rights to assist with integration of refugees within host countries, as well as the provision of identity documents to ensure a protected legal status for refugees in countries of asylum and in the event that they needed to travel further. ${ }^{24}$ This latter area of advice contributed to the creation in July 1922 of the 'Nansen passports', which were named after the High Commissioner and provided a more secure legal status for refugees. ${ }^{25}$

\footnotetext{
${ }^{22}$ Although the contributions of refugees to their own protection have often been underreported, John Hope Simpson undertook a survey between 1937 and 1939 that recorded that from 1917 onwards Russian refugees "established for themselves a large number of organizations for the assistance of their members". This included the Russian Zemstvos and Towns Relief Committee (Zemgor), the old Russian Red Cross and the Federation of Russian Wounded and War Invalids abroad. Similarly, Simpson noted that "from the beginning of the emergency down to the present time, Armenians themselves have made the most substantial contribution to the relief of their own people". For more on this history, see J.H. Simpson, The Refugee Problem: Report of a Survey, Oxford, Oxford University Press, 1939, 172, 180-185; also, P. Gatrell, The Making of the Modern Refugee, Oxford, Oxford University Press, 2013, 57. For analysis of the development of refugee humanitarianism during this period, see M. Barnett, "Refugees and Humanitarianism", in E. Fiddian-Qasmiyeh et al (eds.), The Oxford Handbook of Refugee and Forced Migration Studies, Oxford, Oxford University Press, 2014, 241-252, 245.

${ }^{23}$ Claudena Skran, for example, records that "some private voluntary organizations that engaged in refugee relief were primarily composed of refugees and often spoke out on refugee issues. Other organizations had an overtly political purpose and also claimed to represent refugees": C. Skran, Refugees in Inter-War Europe: The Emergence of a Regime, Oxford, Oxford University Press, 1995, 78.

${ }^{24}$ See "Russian Refugees: Report by Dr. Nansen, High Commissioner of the League of Nations, submitted to the Council on July 20th, 1922", League of Nations Official Journal, 3 (8 - Part II), 1922, Annex 384, 923-928, 925-926.

${ }^{25}$ Initially, the Nansen passports provided refugees with identity documents in host countries, however the capacity of refugees to depart and return to these host countries was limited. In 1926, the Nansen passports were amended to address this issue. Interestingly, in France, Russian and Armenian refugee-led organisations were vested in 1930 with some administrative responsibilities for verifying Nansen passport applications and preparing
} 
Over time, the involvement of refugees in the decision-making processes of the refugee agencies operating under the League of Nations continued to increase. Historian Claudena Skran recorded that by 1934 four of the 13 delegates sent to host countries by the High Commissioner for Refugees and the Nansen International Office were refugees or naturalised refugees, as were four of the five correspondents. ${ }^{26}$ Further, "representatives from leading Russian and Armenian refugee organizations filled two of the twelve places on the Governing Body of the Nansen Office". ${ }^{27}$ Skran added that:

Although refugees were in a minority on the Governing Body, they had added influence because one of them always served on the Managing Committee, a group of three that actually supervised the operations of the Nansen Office. In addition, five of the nine technical advisers to the Nansen Office represented refugee organizations. The presence of these refugee delegates within the League of Nations itself helped to shape the form of refugee assistance. ${ }^{28}$

One of the most significant contributions to emerge from these consultative arrangements between refugees and the League of Nations during the interwar years was the idea proposed by the Russian refugee and jurist, Jacques L. Rubinstein, to develop a binding international convention with respect to refugees. On 7 September 1927, Rubinstein, on behalf of the Russian organisations represented on the Advisory Committee of Private Organisations, recommended a treaty of this kind to be developed under the auspices of the League of Nations. ${ }^{29}$ This proposal was supported by Nansen, who in turn submitted it to the Assembly of the League of Nations for consideration. In June 1928, an inter-governmental conference was convened to deliberate on the scope and terms of such a convention. However, at the time,

related identity documents, with "official confirmation" provided by the representative of the newly established Nansen International Office. This arrangement was made between the French Minister of Foreign Affairs, the Nansen International Office and the Russian and Armenian organisations. For more on this arrangement, see Simpson, The Refugee Problem, 267-268, 299-301. For more on the history of the Nansen passports generally, see L. W. Holborn, “The Legal Status of Political Refugees, 1920-1938”, The American Journal of International Law, 32(4), 1938, 680-703, 684; also, C. Skran, "Historical Development of International Refugee Law", in A. Zimmermann et al (eds.), The 1951 Refugee Convention Relating to the Status of Refugees and its 1967 Protocol: A Commentary, Oxford, Oxford University Press, 2011, 3-36, 7-14.

${ }^{26}$ The Nansen International Office was established in 1930, following the sudden death of Nansen.

${ }^{27}$ Skran, Refugees in Inter-War Europe, 84; also, Simpson, The Refugee Problem, 210.

${ }^{28}$ Skran, Refugees in Inter-War Europe, 84.

29 J. L. Rubinstein, “The Refugee Problem", International Affairs, 15(5), 1936, 716-734, 727-728. 
States were not willing to commit to binding obligations with respect to refugees, and instead adopted the non-binding 1928 arrangement relating to the Legal Status of Russian and Armenian Refugees. ${ }^{30}$

In 1931, the President of the Inter-Governmental Advisory Committee for Refugees of the Council of the League of Nations, Monsieur de Navailles, resurrected the idea of a binding convention, ${ }^{31}$ and, on 28 October 1932, the Governing Body of the Nansen International Office appointed a three person "Committee of Experts" to "consider the advisability of a Convention to ensure the protection of refugees, and to consider certain questions raised regarding the application of the Arrangements of 1922, 1924, 1926, and 1928". ${ }^{32}$ Significantly, two of the three persons appointed to this committee had lived refugee experience. These were the legal scholar and former refugee Baron Boris Nolde, who had escaped in 1919 from Russia to France after the Russian revolution, and the initial proponent of the idea, Rubinstein. ${ }^{33}$ The other appointee was de Navailles, who led the revival of the convention initiative.

During the following year, this Committee of Experts exercised considerable influence and thought-leadership on the development of the 1933 Convention. First, in January 1933 the Committee devised a "simplified procedure" to strategically enable the treaty to be adopted more rapidly than the standard processes would normally allow. This approach was subsequently endorsed by the League on 22 May $1933 .{ }^{34}$ In 1936, reflecting on this strategy, Rubinstein stated

On this occasion different tactics from those of 1928 were employed. There was no attempt to please everybody at the cost of sacrificing the text of the plan; the majority

\footnotetext{
30 "No. 2005 - Legal status of Russian and Armenian refugees”, League of Nations Treaty Series, 89, 1929, 5363. For more on this arrangement, see Holborn, "The Legal Status of Political Refugees, 1920-1938”, 687; also, J. C. Hathaway, "The Evolution of Refugee Status in International Law: 1920-1950" International and Comparative Law Quarterly, 33(2), 1984, 348-380, 354-357.

31 "Resolutions et Voeux Adoptes a la Suite des Rapports de la Sixieme Commission", League of Nations Official Journal, Special Supplement, 92, 1931, 35-38, 38. De Navailles also worked for the Ministry of Foreign Affairs for the French Government.

${ }^{32}$ R. J. Beck, "Britain and the 1933 Refugee Convention: National or State Sovereignty", International Journal of Refugee Law, 11(4), 1999, 597-624, $605 \mathrm{fn}$.

${ }^{33}$ Nolde had also served as vice-president of the Russian Red Cross Society in emigration, and was a member of the Central Juridical Commission for Studying the Status of Russian and Armenian Émigrés. For more on the life and work of Nolde, including his strong focus on legal positivism and his escape from Russia, see P. Holquist, "Dilemmas of an Official with Progressive Views - Baron Boris Nolde", Baltic Yearbook of International Law, 7(1), 2007, 233-271.

${ }^{34}$ Report of the Governing Body of the Nansen International Office for Refugees, A. 12.1934, 3. Cited in Beck, "Britain and the 1933 Refugee Convention", 608.
} 
rule was not applied. All provisions supported by several votes were retained and the governments regarding them as unacceptable were invited to make reservations. ${ }^{35}$

Second, the members of the Committee played an active role in both the drafting of the initial text, as well as in the deliberations that took place during the Inter-Governmental Conference held to discuss the draft Convention between 26-28 October 1933. Rubinstein in particular took a leading role with his colleagues at the Inter-Governmental Advisory Commission in drafting a preliminary version of the document for consideration by States. ${ }^{36}$ Significantly, by the time conference participants agreed upon the final form of the Convention on 28 October 1933, many of the provisions of the final text still closely resembled the draft that Rubinstein and his colleagues had prepared. ${ }^{37}$ Further, while de Navailles was elected President of the InterGovernmental Conference, both Rubinstein and Nolde actively participated in these inter-State negotiations as non-State representatives, featuring frequently in the official transcript of the conference. ${ }^{38}$ Another refugee, Levon Pachalian, also participated on behalf of the Central Committee for Armenian Refugees.

The significance of the 1933 Refugee Convention to contemporary international refugee law has been stressed by several academics over the years. ${ }^{39}$ Yet, most scholars have not mentioned the substantial contributions of refugees to its development, ${ }^{40}$ nor reflected on the

\footnotetext{
${ }^{35}$ Rubinstein, “The Refugee Problem”, 727-728.

${ }^{36}$ Skran, Refugees in Inter-War Europe, 285; Beck, "Britain and the 1933 Refugee Convention", 609.

${ }^{37}$ Beck noted that "Articles I through 16 of the final Convention very closely tracked the draft Convention. As its Article 1, the final Convention included a definition of 'refugee,' though the final Convention essentially followed the draft convention's definition. Article 8 on Industrial Accidents (Draft Article 9) and Article 12 on Education (Draft Article 12) reduced the level of refugee treatment from a 'nationals' standard to, respectively, 'the most favourable treatment ... accord[ed] to the nationals of a foreign country' and 'treatment as favourable as other foreigners in general.' Articles 17 through 23 of the final treaty, which did not figure in the draft, included specific provisions on the treaty's signature, ratification, accession, entry into force, denunciation, its efficacy over colonies, protectorates, and overseas territories, and its amenability to reservation": Beck, "Britain and the 1933 Refugee Convention", 609-610 fn.

${ }^{38}$ Proces Verbaux de la Conference Intergouvernementale Pour Les Refugies, C. 113.M.41.1934. Cited in Beck, "Britain and the 1933 Refugee Convention", 609.

${ }^{39}$ See J. C. Hathaway, The Rights of Refugees under International Law, Cambridge, Cambridge University Press, 2005, 87-91; also, P. Fitzmaurice, "Between the wars - the Refugee Convention of 1933: A contemporary analysis", in D. Keane and Y. McDermott (eds.), The Challenge of Human Rights: Past, Present and Future, London, Edward Elgar Press, 2012, 236-255.

${ }^{40}$ Exceptions to this are Simpson, The Refugee Problem; Skran, Refugees in Inter-War Europe; and Beck, "Britain and the 1933 Refugee Convention". Simpson in particular noted in 1939, without elaborating much further, that "it is above all the Russian refugees who have developed since the (First World) War what may be called the jurisprudence of refugeedom and contributed to political philosophy and practice a concept of the refugee as novel and creative as the concepts of minority and mandate". See Simpson, The Refugee Problem, 108.
} 
significance of this. Although only eight States ratified the Convention, ${ }^{41}$ limiting its operational impact at the time, the 1933 Refugee Convention represents one of the first binding international treaties dealing with the human rights of persons (second only to the 1926 Slavery Convention). ${ }^{42}$ It is also the first occasion where the right to protection from refoulement is articulated in international refugee law. ${ }^{43}$ The obligation of non-refoulement, which prohibits States from returning refugees to any place where their life or freedom is threatened, is now recognised as a central principle of international refugee law. In addition, the 1933 Refugee Convention also codified important socio-economic rights for refugees, including the right to work. This was consistent with Rubinstein's belief that "the right to work is a natural corollary of the right to asylum, a truth too often forgotten". ${ }^{44}$ That refugees and persons with lived refugee experience contributed to the development and implementation of these core tenets of international refugee law remains pertinent today.

\section{CONTRIBUTIONS OF REFUGEES TO THE DRAFTING OF THE 1951 REFUGEE CONVENTION}

In a similar manner to the 1933 Refugee Convention, the historical record of the development of the 1951 Refugee Convention in the aftermath of the Second World War also reveals that refugees or persons with lived refugee experience played a more substantial role in the drafting of the convention than the histories of the era have given credit. Like before, this participation did not take the form of refugees being formally consulted as a recognised group with legal

\footnotetext{
${ }^{41}$ These states were Belgium, Bulgaria, Czechoslovakia, Denmark, France, Italy, Norway and the United Kingdom. Many of these contracting states also made several reservations. See "Refugees", League of Nations Official Journal, Special Supplement, 122, 1934, 106-108; also, Skran, "Historical Development of International Refugee Law", 24.

${ }^{42}$ Hathaway, The Rights of Refugees under International Law, 87.

${ }^{43}$ At the time, refugees and advocates were concerned about the increasing forcible expulsion of refugees from host countries, including at the borders, and sought to contract states to implement effective guarantees to prohibit such practice. For the text of the provision, see Article 3 of the 1933 Refugee Convention. For commentary on this, see G. Goodwin-Gill and J. McAdam, The Refugee in International Law, Oxford, Oxford University Press, 2007, 202.

${ }^{44}$ Rubinstein, “The Refugee Problem”, 729.
} 
authority in their own right. Rather, persons with lived refugee experience occupied senior leadership roles within international organisations that enabled them to contribute to the drafting and deliberation on the text of the treaty. To a limited extent, non-governmental organisations also had the opportunity to participate in official discussions, with some of these organisations being led by representatives who had lived experience of forced displacement. Additionally, at least one State representative involved in the entire treaty process also had experience of being forcibly displaced.

On 8 August 1949, when the United Nations Economic and Social Council (ECOSOC) established an Ad Hoc Committee on Statelessness and Related Problems comprising of 13 States to "consider the desirability of preparing a revised and consolidated convention relating to the international status of refugees and stateless persons", one of the first steps taken by the United Nations Secretariat prior to the first meeting of the Committee was to arrange for a preliminary draft of the convention to be prepared as a starting point for discussion. ${ }^{45}$ Although this draft convention was formally provided by the UN Secretary-General, much of the drafting work of this document was actually completed by the legal division of the International Refugee Organisation (IRO), which had been established by the UN in December 1946 as a non-permanent organisation mandated to assist the repatriation, resettlement and integration of refugees still displaced after the Second World War.

At the time, many of the IRO lawyers responsible for penning this initial draft had, as Irial Glynn records, "personal experience of asylum". ${ }^{46}$ In particular, the individual who according to the archival record completed most of this preliminary drafting work $^{47}-$ Paul Weis - had lived experience of being interned in Dachau concentration camp from November 1938 to April 1939, before fleeing to Britain in 1939 and becoming a naturalised British subject

\footnotetext{
${ }^{45}$ UN ECOSOC, Resolution 248 (IX) B, UN Doc. E/1553, 8 Aug. 1949. This resolution followed on from the UN ECOSOC study completed on 1 Aug.1949 on statelessness and related problems. See UN ECOSOC, A Study of Statelessness, United Nations, August 1949, Lake Success - New York, UN Doc E/1112; E/1112/Add.1, 1 Aug. 1949.

${ }^{46}$ I. Glynn, "The Genesis and Development of Article 1 of the 1951 Refugee Convention", Journal of Refugee Studies, 25(1), 2011, 134-148, 136.

${ }^{47}$ Although the UN Secretariat vested Kullman with the overall responsibility for the preparation of the Ad Hoc Committee draft of the 1951 Refugee Convention, evidence from Weis' personal archive reveals that it was actually Weis who completed most of this preliminary drafting work, in both the English and French versions of the text: Paul Weis Archive PW/PR/IRO-6 Doc. 32 at 3. Cited in Ben-Nun, "The Israeli Roots of Article 3 and Article 6 of the 1951 Refugee Convention", 107. The Weis archive is now held at the Refugee Studies Centre at Oxford University.
} 
in 1947.48 Some of the other personnel who assisted Weis included Rubinstein, who (as discussed previously) was a former Russian refugee who played a prominent role in the drafting of the 1933 Convention sixteen years earlier, and the Swiss jurist Gustave Kullman. Although Kullman did not have direct refugee experience, his wife, Maria Mikhailovna Zernova Kullmann, had also been forced to flee Russia after the 1917 Revolution. ${ }^{49}$

The initial draft that these IRO lawyers prepared and presented to the Ad Hoc Committee for its first meeting on 3 January 1950 played a key role in shaping the scope, substance and strategy of the treaty negotiations in several ways. First, they established the strategy that would be taken throughout the drafting process. They outlined that the Convention should be adopted by the greatest number of States possible, and thus it was important to prepare a "realistic draft" 50 that did not impose upon States "obligations greater than those which they are prepared to accept", but at the same time ensured that the Convention did not fall short "of what some States might be prepared to grant". ${ }^{1}$ Second, they articulated the importance of developing a definition of a refugee that reflected the diversity of refugee experiences, suggesting different pathways for pursuing this. At the time, the immediate history of the Holocaust haunted those involved in the drafting process, but there was still recognition, as Rubinstein recorded, that "not all refugees represented people displaced by war". 52

Third, they ensured the inclusion of several socio-economic rights in the draft. Perhaps in part due to Rubinstein's influence, several of these provisions were modelled on provisions from the 1933 Refugee Convention. Lastly, the draft made arguably the most explicit statement found in the entirety of the drafting documents as to the purpose and importance of the principle of non-refoulement, stating that "the turning back of a refugee to the frontier of the country where his life or liberty is threatened on account of his race, religion, nationality or political opinions... would be tantamount to delivering him into the hand of his persecutors". ${ }^{53}$ This

\footnotetext{
${ }^{48}$ I. Jackson, "Paul Weis", The Independent, London, 18 February 1991, 13; also S. J. A. Flynn, "The Weis Archive and Library Collection at the Refugee Studies Programme", Journal of Refugee Studies, 9(1), 1996, 8995, 89-90.

${ }^{49}$ Glynn, "The Genesis and Development of Article 1 of the 1951 Refugee Convention", 136.

${ }^{50}$ Quote of Gustave Kullman. Cited in Glynn, "The Genesis and Development of Article 1 of the 1951 Refugee Convention", 136.

${ }^{51}$ UN ECOSOC, Ad Hoc Committee on Statelessness and Related Problems, Status of Refugees and Stateless Persons - Memorandum by the Secretary-General, UN Doc. E/AC.32/2, 3 Jan. 1950.

${ }^{52}$ Rubinstein Letter to Weis, 3 Feb. 1950, PW/PR/IRO/6. Cited in Glynn, "The Genesis and Development of Article 1 of the 1951 Refugee Convention", 138.

${ }^{53}$ UN ECOSOC, Ad Hoc Committee on Statelessness and Related Problems, Status of Refugees and Stateless Persons - Memorandum by the Secretary-General.
} 
statement has subsequently been referenced to inform important case law precedents, ${ }^{54}$ as well as UNHCR advisory opinions. ${ }^{55}$

Despite these contributions, in comparison to the drafting process of the 1933 Refugee Convention, the IRO draft was subject to far greater scrutiny, debate and revision than the relatively straightforward two-day formal deliberation that the 1933 Convention received. Between the first meeting of the Ad Hoc Committee on 3 January 1950 and the adoption of the Convention on 28 July 1951, almost every provision of the 1951 Refugee Convention was closely analysed and questioned, as the extensive historical materials of this period demonstrate. These deliberations took place firstly during the discussions of the Ad Hoc Committee between January and August 1950, and then later during UN ECOSOC meetings and meetings of the UN General Assembly. Finally, extensive discussions occurred at the Conference of Plenipotentiaries held in July 1951 in the lead up to the treaty's adoption.

Throughout these discussions, States clearly exercised ultimate decision-making power in the determination of international refugee law. This can be seen most notably by the removal of any references to the right to seek asylum in the text (which the IRO draft had initially included), along with the addition of temporal and geographical limitations to the refugee definition. Nevertheless, persons with lived refugee experience continued to make notable interventions which influenced some of the outcomes of the text. Among them, Weis appeared as the representative for the IRO during this process, before taking on the role of Legal Advisor at UNHCR when the IRO disbanded. ${ }^{56}$ As discussed in the following section, the High Commissioner, Gerrit Jan Van Heuven Goedhart, also appeared on behalf of UNHCR.

Another prominent participant with lived refugee experience throughout this process was the representative for the Israeli State - the Jewish international lawyer Jacob Robinson. ${ }^{57}$ Although not an Israeli citizen nor part of the Israeli political establishment, Robinson was selected to represent Israel throughout the process following his extensive experience in international law, including his work in relation to the protection of minorities during the years of the League of Nations and his work assisting the prosecutorial team during the Nuremberg

\footnotetext{
${ }^{54}$ See, for example, Sale v. Haitian Centers Council, 509 U.S. 155 (1993), dissenting judgment of Blackmun J.

${ }^{55}$ See UNHCR, Advisory Opinion on the Extraterritorial Application of Non-Refoulement Obligations under the

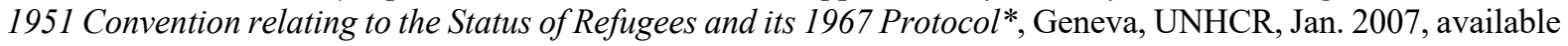
at: https://www.refworld.org/docid/45f17ala4.html (last visited 1 Sep. 2020), para. 30.

${ }^{56}$ Although not discussed in this paper, Weis also contributed to the development of the 1967 Protocol.

${ }^{57}$ To avoid confusion, it is worth noting that Jacob Robinson's brother, Nehemiah Robinson, also participated in the Conference of Plenipotentiaries as a non-governmental organisation representative and later published the first legal commentary of the 1951 Refugee Convention in 1955.
} 
Trials. ${ }^{58}$ Born in Lithuania, Robinson also had personal experience of political persecution, having been a member of the Lithuanian parliament before an army coup d'état in 1926 led to Jews and other minorities being prohibited from participating in further political activity. $\mathrm{He}$ also had been forced to flee Lithuania in May 1940, shortly prior to the Soviet occupation of the country. He recorded in an interview that he and his family were able to reach safety in New York, after fleeing across several European countries and boarding a vessel in Lisbon. ${ }^{59}$

During the deliberations on the 1951 Refugee Convention, Robinson played a central role in strategically securing passage of some key rights contained in the Convention. As BenNun has recorded, Robinson effectively negotiated with States to overcome concerns in relation to the application of the non-discrimination clause, ultimately drafting the version of the article that was finally adopted and masking some of the discontent among dissatisfied States. This achievement, as Ben-Nun notes, "cannot be underestimated" as "no such clause regarding non-discrimination between different refugees, or between refugees and other aliens, had existed in previous international instruments". ${ }^{60}$ Further, during the second session of the Conference of Plenipotentiaries, Robinson also strategically secured procedural acceptance that the draft of the treaty prepared by the Ad Hoc Committee (with significant input from Weis) be used as the base text for discussion. ${ }^{61}$ This procedural victory was significant as the French Government had also prepared a draft for consideration which was more restrictive in terms of refugee rights.

In addition to this, Robinson also made frequent submissions on many of the other treaty provisions. These submissions not only influenced the drafting of the text at the time, but they have also continued to guide the interpretation of the treaty in accordance with the rules of treaty interpretation under international law. For example, in relation to the scope of the refugee definition, Robinson clearly noted that the definition did not extend to persons fleeing natural disasters or other environmental problems. He stated that "it was difficult to imagine that fires, floods, earthquakes or volcanic eruptions, for instance, differentiated

\footnotetext{
${ }^{58}$ For more on Robinson's prior legal experience, see Kaplan-Feuereisen and Mann, "At the Service of the Jewish Nation: Jacob Robinson and International Law"; also, Ben-Nun, "The Israeli Roots of Article 3 and Article 6 of the 1951 Refugee Convention", 105-106. Robinson also had a close working relationship with Weis, as he had served as his direct supervisor when they both worked at the World Jewish Congress in the period after the Second World War.

${ }^{59}$ Kaplan-Feuereisen and Mann, "At the Service of the Jewish Nation: Jacob Robinson and International Law", 166.

${ }^{60}$ Ben-Nun, "The Israeli Roots of Article 3 and Article 6 of the 1951 Refugee Convention”, 113.

${ }^{61}$ Ibid., 111.
} 
between their victims on the grounds of race, religion or political opinion". ${ }^{62} \mathrm{He}$ also specified that the instrument did not "cover all man-made events. There was no provision, for example, for refugees fleeing from hostilities unless they were otherwise covered by article 1 of the Convention". ${ }^{63}$ These submissions have contributed to understandings of the object and purpose of Article 1A(2) of the Refugee Convention, and have also informed more recent debates about the appropriateness of the Convention to respond to persons displaced by climate-change related events. These submissions also highlight that not all contributions of refugees or persons with lived refugee experience have sought to progressively expand the protection of forcibly displaced persons under international law. While Robinson advocated for progressive rights protections in many areas, some of his contributions sought to limit these protections to particular claimants.

Although there is no record of Robinson discussing his personal experience of displacement during these deliberations, Robinson was cognisant at the time that despite formally representing Israel during the negotiations, his refugee experience was also relevant, particularly in relation to the moral legitimacy this evoked. For example, in a telegram written to the Israeli Foreign Minister Sharett on 1 August 1951, Robinson noted that he had been unable to attend the ceremony to first sign the Convention on 28 July 1951 because it was scheduled on the Sabbath. However, he indicated that he had informed the President of the Conference Knud Larsen of this scheduling issue, and the President "expressed his regret that I would not be among the first signers, particularly because I represented, in his view, not only a government, but also morally the refugee as such". ${ }^{64}$

Finally, refugees also contributed to the drafting and deliberation of the 1951 Refugee Convention as representatives of non-governmental organisations during the discussions. One of the most notable civil society interventions given its impact on the final text of the Convention was that put forward by the Rabbi Isaac Lewin on behalf of the Jewish nongovernmental organisation Agudas Israel World Organisation. Lewin, who had escaped to New York following the German occupation of Poland in 1939, was invited to speak at the Ad Hoc Committee on the request of the representative of USA, Louis Henkin. ${ }^{65}$ On this occasion,

\footnotetext{
${ }^{62}$ Conference of Plenipotentiaries on the Status of Refugees and Stateless Persons, Summary Records, $22^{\text {nd }}$ meeting, UN doc. A/CONF.2/SR.22, 26 Nov.1951.

${ }^{63}$ Ibid.

${ }^{64}$ Cited in G. Ben-Nun, "The British-Jewish Roots of Non-Refoulement and its True Meaning for the Drafters of the 1951 Refugee Convention”, Journal of Refugee Studies, 28(1), 2014, 93-117, 112.

${ }^{65}$ Ibid., 102.
} 
Lewin proposed a new wording and structure of what is now Articles 32 and 33 of the Convention, which was selected by the Committee as the best draft for the basis of further discussion. In this draft, Lewin proposed a procedural guarantee, namely that "the refugee shall have the right to submit evidence to clear himself and to appeal to be represented before competent authority", which was ultimately retained in the final text. ${ }^{66}$

Significantly, archival evidence suggests that Lewin at the time also sought to provide some religious underpinning to the significance of the provisions, reciting "long quotations from the book of Amos" in relation to the issues of expulsion and refoulement. ${ }^{67}$ However, none of these religious statements were documented in the official UN transcripts of the meeting. This evidence suggests that some caution is needed when reviewing official records of the travaux préparatoires, as they are not verbatim transcripts of what was discussed. ${ }^{68}$ It is not beyond the realm of possibility that further discussions as to individuals' personal experiences or reflections were left out of the official transcript of proceedings because they were either not considered significant or not considered desirable for inclusion within a legal positivist discourse seeking neutral, objective statements of law and intent.

\section{CONTRIBUTIONS OF GERRIT JAN VAN HEUVEN GOEDHART TO THE FOUNDATIONAL YEARS OF UNHCR, 1950-1955}

A third significant contribution of refugees to the development of international refugee law and policy was the involvement of refugees in the early years of UNHCR. It is one of the lesser reported facts of the international refugee regime and the history of UNHCR that the first High Commissioner of UNHCR, Gerrit Jan Van Heuven Goedhart, had lived experience of being forcibly displaced as a consequence of Nazism and the Second World War. ${ }^{69}$ Prior to his

\footnotetext{
${ }^{66}$ UN ECOSOC, Ad Hoc Committee on Statelessness and Related Problems, First Session: Summary Record of the Nineteenth Meeting Held at Lake Success, New York, on Wednesday, 1 February 1950, at 11 a.m., UN Doc. E/AC.32/SR.19, 8 Feb. 1950, para. 53.

${ }^{67}$ G. Ben-Nun, "The British-Jewish Roots of Non-Refoulement and its True Meaning for the Drafters of the 1951 Refugee Convention",103-104.

${ }^{68}$ J. McAdam, "Interpretation of the 1951 Refugee Convention", in A. Zimmermann et al (eds.), The 1951 Refugee Convention Relating to the Status of Refugees and its 1967 Protocol: A Commentary, Oxford, Oxford University Press, 2011,75-116, 100.

${ }^{69}$ For example, Van Heuven Goedhart's experience of forced displacement is not mentioned in UNHCR's brief biography of his life: UNHCR, "Gerrit Jan van Heuven Goedhart (Netherlands): 1951-1956", Geneva, UNHCR, available at: https://www.unhcr.org/en-au/gerrit-jan-van-heuven-goedhart-netherlands-19511956.html (last visited 1 Sep. 2020). A similar version of this biography is also found in UNHCR, The State of the World's Refugees, 2000: Fifty Years of Humanitarian Action, Oxford, Oxford University Press, 2000, Annex 11, 326.
} 
appointment as High Commissioner in 1950, Van Heuven Goedhart was forced to flee the Netherlands in 1944 for fear of persecution by German-occupied forces. At the time, Van Heuven Goedhart was working as co-editor of the underground newspaper Het Parool, which was circulated by the Dutch Resistance during the German occupation of the Netherlands between 1940 and 1945. While working at the newspaper, 37 of his colleagues were executed, and several others were arrested and interned in concentration camps. ${ }^{70}$ His brother was also executed, ${ }^{71}$ and the German forces offered a reward for Van Heuven Goedhart's capture. Ultimately, Van Heuven Goedhart was able to escape and seek refuge in London, where he was appointed Minister of Justice in the Netherlands Government in exile.

The historical record of Van Heuven Goedhart's tenure as the first High Commissioner of UNHCR suggests that, rather than trying to downplay the significance of this personal life experience on his work and thinking in relation to refugee protection, Van Heuven Goedhart often made key interventions which drew on his personal experience of forced displacement. ${ }^{72}$ For example, on 13 December 1950, when the General Assembly considered his potential appointment as the first High Commissioner, Van Heuven Goedhart submitted a curricula vitae which explicitly mentioned that he had served in the resistance movement in the Netherlands and had escaped to England in $1944 .^{73}$ Clearly, Van Heuven Goedhart saw some value in including this information for consideration by Member States, alongside his later experience as Chairman of the Netherlands Delegation to the General Assembly. In contrast, the other candidate recommended by the UN Secretary-General for consideration, the American J. Donald Kingsley, had served as the Director-General of the International Refugee Organisation, but had no lived experience of displacement. ${ }^{74}$

\footnotetext{
70 "Dr. Van Heuven Goedhart: Tireless Worker for Refugees", The Times, London, 10 Jul. 1956, 13.

${ }^{71}$ G. Loescher, The UNHCR and World Politics: A Perilous Path, Oxford, Oxford University Press, $2001,52$.

72 This approach is distinct from that taken by Paul Weis, who rarely mentioned or discussed his personal experience of displacement in his published or recorded works. See, for example, P. Weis, "Legal Aspects of the Convention of 25 July 1951 Relating to the Status of Refugees", British Yearbook of International Law, 30, 1953, 475-512; also, P. Weis, “The International Protection of Refugees”, American Journal of International Law, 48(2), 1954, 193-221; also, P. Weis, "Development of Refugee Law”, Michigan Yearbook of International Legal Studies, 3, 1982, 27-42.

${ }^{73}$ Election of the High Commissioner for Refugees: Note by the Secretary General, $5^{\text {th }}$ sess., Agenda item 32(3), UN Doc A/1716, 13 Dec. 1950, 2.

${ }^{74}$ It is unclear from the historical record how much importance UN Member States at the General Assembly placed on this personal experience when appointing Van Heuven Goedhart instead of Kingsley, particularly given that the vote was conducted by secret ballot. Historical analysis of this appointment undertaken so far has focused on the political tensions between the United States, who preferred their own citizen Kingsley, and British and Commonwealth states, who favoured a candidate from a more neutral country. See Loescher, The UNHCR and World Politics, 51-52; also, G. Ben-Nun, “The Expansion of International Space: UNHCR's Establishment of its Executive Committee ("ExCom")", Refugee Survey Quarterly, 36(1), 2017, 1-19, 8; also, S. L. Carruthers,
} 
Further, Van Heuven Goedhart also referred to his personal experience of displacement to inform debate during the drafting of the 1951 Refugee Convention. In particular, during discussion on the draft article of what is now Article 31 of the Refugee Convention on "Refugees unlawfully in the country of refuge", Van Heuven Goedhart discussed his escape to England to reinforce support for immunity for refugees from penalties in situations where they are required to transit through other countries in search of protection. The travaux préparatoires of the $14^{\text {th }}$ meeting of the Conference of Plenipotentiaries recorded Van Heuven Goedhart stating that:

in 1944, he had himself left the Netherlands on account of persecution and had hidden in Belgium for five days. As he had run the risk of further persecution in that country, he had been helped by the resistance movement to cross into France. From France he had gone on into Spain, and thence to Gibraltar. Thus, before reaching Gibraltar, he had traversed several countries in each of which the threat of persecution had existed. ${ }^{75}$

Van Heuven Goedhart argued that "it would be very unfortunate if a refugee in similar circumstances was penalized for not having proceeded direct to the country of asylum". ${ }^{76}$ Ultimately, the version of Article 31(1) finally adopted prohibits States parties from imposing penalties on refugees, on account of their illegal entry or presence, provided that they are "coming directly from a territory where their life or freedom was threatened", "present themselves without delay" and "show good cause for their illegal entry or presence". ${ }^{77}$ The travaux préparatoires, of which Van Heuven Goedhart's statements as High Commissioner form part, assist in interpreting the clauses "coming directly" and "good cause" in a manner

\footnotetext{
"Between Camps: Eastern Bloc "Escapees" and Cold War Borderlands", American Quarterly, 57(3), 2005, 911 942, 921. The New York Times did however discuss Van Heuven Goedhart's personal experience of displacement in its reporting of his appointment: "Dutch Editor gets U.N. Refugee Post", New York Times, New York, 15 Dec. 1950, 21. For more on Kingsley's experience, see “Donald Kingsley, Aided U.N. Agency”, New York Times, New York, 2 Jun. 1972, 41.

${ }^{75}$ This record is a summary of Van Heuven Goedhart's statement, rather than a verbatim transcript: Conference of Plenipotentiaries on the Status of Refugees and Stateless Persons, Summary Records, $14^{\text {th }}$ meeting, UN doc. A/CONF.2/SR.14, 22 Nov. 1951.

${ }^{76}$ Ibid.

${ }^{77}$ For more on the drafting history of this provision, see G. S. Goodwin-Gill, "Article 31 of the 1951 Convention Relating to the Status of Refugees: non-penalization, detention, and protection", in E. Feller, V. Türk and F. Nicholson (eds.), Refugee Protection in International Law: UNHCR's Global Consultations on International Protection, Cambridge, Cambridge University Press, 2003, 185-252, 191-193.
} 
which prohibits States from penalising refugees in situations where they transit through one or more countries because they are either still at risk or no protection is available. ${ }^{78}$

In addition to these direct references to his personal experience, Van Heuven Goedhart's experience as both a refugee and the head of an international organisation also likely influenced his thinking on the importance of consulting with refugees in decisions that affect them and the trajectory of UNHCR's work in the early years. For example, speaking at the beginning of his tenure about the need for UNHCR to establish field offices in all countries where large numbers of refugees reside, Van Heuven Goedhart stressed the importance of direct communication between UNHCR and refugees for the effective implementation of UNHCR's mandate: "If the international protection of refugees is to mean anything", Van Heuven Goedhart stated, "it must mean that refugees are at least able to see and talk to a representative of the authority which is supposed to be protecting them". ${ }^{79}$ For the five years that Van Heuven Goedhart served as High Commissioner, he devoted significant time and energy towards establishing and securing funding for these branch offices. In accordance with UNHCR's mandate, these field offices were located not only in Europe, but also in locations such as Cairo, Bogotá and Hong Kong. ${ }^{80}$ This field-based approach to protection remains a core component of UNHCR's work.

Similarly, Van Heuven Goedhart also sought to cultivate an understanding and perception of refugees within international law and policy making that reinforced their agency and economic potential, rather than seeing them as passive victims in need of humanitarian aid. Following his acceptance, on behalf of UNHCR, of being awarded the 1954 Nobel Peace Prize, Van Heuven Goedhart stated in December 1955 that:

\footnotetext{
${ }^{78}$ See ibid., 255-256; also, $R$ v. Uxbridge Magistrates Court and Another, Ex parte Adimi [1999] 4 All ER 520 (UK), paras. 16-26. It is worth noting that several academics have quoted Van Heuven Goedhart as saying, in relation to a proposal to include sex as a ground for protection from discrimination during the drafting of Article 3 of the 1951 Refugee Convention, that "he doubted strongly whether there would be any cases of persecution on grounds of sex". This quote, however, has been incorrectly attributed, and was actually a summary record of a statement made by the President of the Conference, Knud Larsen of Denmark. The summary record indicates that Van Heuven Goedhart did not comment on this proposal at the time. See Conference of Plenipotentiaries on the Status of Refugees and Stateless Persons, Summary Records, $5^{\text {th }}$ meeting, UN doc. A/CONF.2/SR.5, 19 Nov.1951. ${ }^{79}$ G. J. Van Heuven Goedhart, "Address to the 7th Session of the General Council of the International Refugee Organization", Geneva, UNHCR, 9 Apr. 1951, available at: https://www.unhcr.org/en$\mathrm{au} / \mathrm{admin} / \mathrm{hcspeeches} / 3 \mathrm{ae} 68 \mathrm{fce}$ /address-dr-gerrit-jan-van-heuven-goedhart-united-nations-highcommissioner.html (last visited 1 Sep. 2020).

${ }^{80}$ For more on the establishment of UNHCR's field offices, see Report of the United Nations High Commissioner for Refugees, $9^{\text {th }}$ sess, Supp No.13, UN Doc A/2646, 1 Jan. 1955, paras. 39-48; also, G. J. Van Heuven Goedhart, "Speech at the meeting of Swiss Aid to Europe", Berne, UNHCR, 19 Feb. 1953, available at: https://www.unhcr.org/en-au/admin/hcspeeches/3ae68fb630/speech-made-dr-gerrit-jan-van-heuven-goedhartunited-nations-high-commissioner.html (last visited 1 Sep. 2020).
} 
The refugee problem has nothing to do with charity. It is not the problem of people to be pitied but far more the problem of people to be admired. It is the problem of people who somewhere, somehow, sometime had the courage to give up the feeling of belonging, which they possessed, rather than abandon the human freedom which they valued more highly. ${ }^{81}$

Consistent with this thinking on the individual agency of refugees, Van Heuven Goedhart and UNHCR introduced several initiatives to support the economic self-reliance and integration of refugees during these early years of UNHCR's work. These initiatives included housing schemes in areas in need of employment, where refugees not only "helped with the building of their future homes", but also committed to "repay the cost of the houses over a stipulated period and provision has been made that the money repaid will be used to benefit other refugees". ${ }^{82}$ These housing schemes were primarily implemented in Germany and Austria, and were designed to transition refugees out of refugee camps in the area. ${ }^{83}$ The initiatives also included funding for vocational training, ranging from apprenticeships to university scholarships, as well as small business loans to assist refugees establish new enterprises, particularly in the agricultural sector. ${ }^{84}$ Many of these initiatives were financially supported through publicprivate partnerships, particularly with the support of the Ford Foundation, on the proviso that were "designed to help refugees to help themselves rather than to remedy their situation temporarily". ${ }^{85}$ Several of these ideas resemble contemporary approaches to refugee selfreliance and integration, including those found in the New York Declaration and the Global Compact on Refugees. ${ }^{86}$

\footnotetext{
${ }^{81}$ G. J. Van Heuven Goedhart, "Refugee Problems and their Solutions", Oslo, UNHCR, 12 Dec. 1955, available at: https://www.unhcr.org/en-au/admin/hcspeeches/3ae68fb918/refugee-problems-solutions-address-dr-gerritjan-van-heuven-goedhart-united.html (last visited 1 Sep 2020). Van Heuven Goedhart's comments in relation to freedom should also be read in the intensely political Cold War context in which he served his role. For more on this context, see Loescher, The UNHCR and World Politics, 50-75; also, on the politics surrounding the mandate of UNHCR, see UN General Assembly, $325^{\text {th }}$ Plenary Meeting, ${ }^{\text {th }}$ sess, UN Doc A/PV.325, 14 Dec.1950, paras. $72-75,81$.

${ }^{82}$ Report of the United Nations High Commissioner for Refugees (1955), para. 224.

${ }^{83}$ Ibid.

${ }^{84}$ Ibid.

${ }^{85}$ Ibid., para. 220. See further, G. J. Van Heuven Goedhart, "People Adrift", Journal of International Affairs, 7(1), 1953, 7-29, 27.

${ }^{86}$ See New York Declaration, Annex 1: Comprehensive refugee response framework, para. 13; also, Global Compact on Refugees, para. 7. The outcomes of these initiatives merit further research given their relevance to contemporary approaches to refugee self-reliance. For more on the history of refugee self-reliance, see E. Easton-
} 
Finally, in relation to durable solutions, Van Heuven Goedhart emphasised his view that refugees should have some autonomy in making decisions about the appropriateness of different durable solutions that may be available to them. ${ }^{87}$ While recognising at the time that governments were already placing significant restrictions on the availability of durable solutions for refugees, Van Heuven Goedhart stated in 1955 that "freedom of decision is the inalienable right of the refugee himself. It is his wish that counts, and the United Nations, within the limits of the Statute, try to fulfil that wish, no matter what it is - repatriation, resettlement or integration". ${ }^{88}$ This statement is consistent with contemporary commitments that refugees should have a say in all decisions that affect them. However, too often in the history of international refugee regime, States have denied refugees the capacity to exercise some choice in the selection of the most appropriate durable solution for their circumstances. ${ }^{89}$ This has in turn led to worse outcomes for refugees and States, as well as greater inefficiencies for the regime. ${ }^{90}$

\section{COMMENTARY}

Calabria and N. Omata, "Panacea for the refugee crisis? Rethinking the promotion of 'self-reliance' for refugees", Third World Quarterly, 39(8), 2018, 1458-1474; also, C. Skran and E. Easton-Calabria, "Old Concepts Making New History: Refugee Self-reliance, Livelihoods and the 'Refugee Entrepreneur"', Journal of Refugee Studies, $33(1), 2020,1-21$.

87 The term 'durable solutions' commonly refers to the triad of solutions comprising the voluntary repatriation of refugees to their country of origin, the local integration of refugees in the country of asylum, and the resettlement of refugees to a third country. During Van Heuven Goedhart's tenure, the term was not commonplace. Albert Kraler et al state that the term features more prominently in UNHCR sources from the late 1970s onwards, notably with the establishment of a UNHCR fund for durable solutions in 1980. Nevertheless, Van Heuven Goedhart contributed to the conceptual evolution of this term, frequently discussing the solutions of repatriation, resettlement and local integration alongside one another. For more on the history of the term, see A. Kraler et al, "Learning from the past: Protracted displacement in the post-World War II period", TRAFIG: Transnational Figurations of Displacement, TRAFIG Working Paper No. 2, Feb. 2020, available at: https://trafig.eu/output/working-papers/trafig-working-paper-no-2/D021-TWP-Learning-from-the-past-Kraleret-al-2020-v2p-2020-03-04.pdf (last visited 1 Sep. 2020) 9-10.

${ }^{88}$ Van Heuven Goedhart, "Refugee Problems and their Solutions".

${ }^{89} \mathrm{UNHCR}$ also has communicated to refugees more recently that they are not entitled to apply for resettlement themselves, and that, if they fit the criteria for resettlement, they will be contacted by UNHCR. See T. de Boer and M. Zieck, "The Legal Abyss of Discretion in the Resettlement of Refugees: Cherry-Picking and the Lack of Due Process in the EU", International Journal of Refugee Law, 32(1), 2020, 54-85, 61.

${ }^{90}$ See, for example, W. Jones and A. Teytelboym, "The Local Refugee Match: Aligning Refugees' Preferences with the Capacities and Priorities of Localities", Journal of Refugee Studies, 31(2), 2017,152-178, 154-157; also, V. Barbelet, J. Hagen-Zanker and D. Mansour-Ille, "The Jordan Compact: lessons learnt and implications for future refugee compacts", Overseas Development Institute, 2018, available at: www.odi.org/publications/11045jordan-compact-lessons-learnt-and-implications-future-refugee-compacts (last visited 1 Sep. 2020) 5. 
The historical evidence examined in the previous three parts of this article reveal that refugees and persons with lived refugee experience played a far more substantive role in the development of international refugee law and policy than previously acknowledged. Although the participation of refugees in formal decision-making processes was limited - refugees as a categorised group held no formal decision-making power, and matters of international law remained principally inter-State undertakings - in the years between 1921 and 1955, refugees and persons with lived refugee experience not only actively participated in the formal deliberations of the 1933 Refugee Convention and the 1951 Refugee Convention, but they also played key roles in the preparatory drafting of these instruments. Further, refugees and persons with lived refugee experience also held senior leadership positions within international organisations, civil society organisations and refugee-led organisations established at the time to provide protection for refugees. Their involvement in these organisations often influenced the focus and direction of this work.

The contributions of refugees to the development of early international refugee law and policy are significant because they shift our understanding of the ways in which international refugee law was developed and negotiated. In particular, these contributions challenge the idea that early international refugee law was solely negotiated based on the different, and at times competing, political agendas of nation States. Breaking away from the "theoretical straight jacket" of the nation State, ${ }^{91}$ it is clear that refugees and persons with lived refugee experience clearly played influential roles in designing some of the strategies employed during these treaty-making periods, which altered the trajectory of legal and policy development. Second, these contributions also challenge the assumption that refugee voices have largely been ignored in international law and policy making until very recently. This latter recognition creates the opportunity to reflect on these contributions and consider what lessons can be ascertained from these events for future initiatives seeking to more meaningfully include refugees in the design and implementation of international refugee law and policy.

From a normative perspective, several insights can be gained from reflecting on these contributions. First, the inclusion of refugees in the development of early international refugee law and policy enhanced the specificity and practical application of particular legal provisions and policy choices, drawing in part on the lived realities of refugee displacement and experience. This inclusion in turn led to better outcomes for both refugees and States, and is

${ }^{91}$ Ben-Nun, "The Expansion of International Space”, 17. 
consistent with the recognition in the Global Compact on Refugees that "responses are most effective when they actively and meaningfully engage those they are intended to protect and assist". ${ }^{92}$ Some notable examples of the instrumental value of participatory initiatives include Van Heuven Goedhart's intervention on the wording of Article 31 of the Refugee Convention on "Refugees unlawfully in the country of refuge", as well as the evolution of the nonrefoulement principle, from its legal origins in the 1920s and 1930s to its development in the 1951 Refugee Convention. The enduring relevance of these provisions is in part testament to the practical necessity of these protections for refugees, both then and now.

Second, formative ideas, such as the proposal to develop a binding international legal convention for refugees, emerged in an environment where refugee organisations and representatives had direct, sustained and systematic communication with States and international organisations over several years. Measures were in place in which these ideas could be recognised and debated, and then implemented. When Rubinstein first proposed the idea of a binding international convention relating to refugees in 1927, Nansen and the League of Nations were able to act on the suggestion within a matter of weeks, even though it took a further six years before States adopted the first binding treaty on refugees. The prompt consideration of Rubinstein's idea was in part due to the established communication channels that were already in place between the League of Nations and refugee organisations dating back to 1921, as well as the cultural and political acceptance at the time of the value and importance of these types of collaboration.

Third, the contributions of refugees to formal treaty-making negotiations, both during the 1933 Convention and the 1951 Convention, did not undermine State sovereignty or the legitimacy of these instruments. In 1936, the British Government expressed some concern that non-State actor participation in the development of international refugee law should be minimised, suggesting that they "should have been treated on the same footing as the press and other members of the public".93 However, overwhelmingly States tacitly supported the contributions of refugees to these legal and policy decision-making processes, with very little evidence in the historical record suggesting that States complained or were concerned about this type of involvement. Refugees also contributed to this type of mutual collaboration, providing not only access to information that only they possessed, but also putting forward

\footnotetext{
92 Global Compact of Refugees, para. 34.

${ }^{93}$ Quote of Roger Makins, cited in Beck, "Britain and the 1933 Refugee Convention”, 617.
} 
"realistic" rights-based proposals that recognised the continuing importance of sovereignty for nation States. This approach is reflective of what Devika Hovell has labelled a "public interest model of law", where "increased opportunities for participation in decision making strengthen the bonds of rational consent between individuals and decisions", and "respect for decisionmaking authority is negotiated, not won by subordination to formal rules". ${ }^{4}$

Fourth, the active involvement of refugees in the development of early international refugee law is evidence that refugees identified the promising potential of international law, and the value of being recognised as specific subjects of international law with corresponding rights and responsibilities. For some, engagement in processes relating to the development of international law were no doubt in part to "push the behaviour of states toward outcomes other than those predicted by power and the pursuit of national interest". ${ }^{95}$ Refugees and persons with lived refugee experience saw the potential of international law as being capable of setting benchmarks for States and other actors, establishing and reinforcing best practices and influencing the development and implementation of national law and policy. ${ }^{96}$ They also firmly established that refugee protection was an issue that demanded international cooperation. ${ }^{97}$ Like many States, refugees participating in these processes stressed the humanitarian nature of refugee protection. However, they were also acutely aware of the political nature of international refugee protection, which led to some groups of refugees receiving protection but not others. As Rubinstein remarked in 1936, "refugee work more than anything else should be free from political considerations. Unhappily, experience shows that humanitarian activities cannot escape from association". ${ }^{98}$

\footnotetext{
${ }^{94}$ D. Hovell, "Due Process in the United Nations", The American Journal of International Law, 110(1), 2016, 148, 7. Following the adoption of the 1951 Refugee Convention, Van Heuven Goedhart commented in a letter to the New York Times that "In the present tense international situation, when Governments are concerned with questions of security, it would have been unrealistic to expect that the final text of the convention would be extremely liberal. However, any impartial person who studies the text must recognize that the convention marks a decisive step toward the establishment of reasonable average standards for the rights of refugees": G. J. Van Heuven Goedhart, "Letters to the Times: Rights of Refugees", New York Times, New York, 15 Sep. 1951, 14.

${ }^{95}$ A. Slaughter Burley, "International Law and International Relations Theory: A Dual Agenda", American Journal of International Law, 87(2), 1993, 205-239, 206.

${ }^{96}$ See R. Howse and R. Teitel, "Beyond Compliance: Rethinking Why International Law Really Matters", Global Policy, 1, 2010, 127-136, 127.

${ }^{97}$ Writing in 1939, Simpson argued that the political effect of the efforts of refugee leaders "to obtain increasing definition of their status as refugees through a series of international instruments... has been to perpetuate their position as refugees, and to stabilize on an international basis a security as refugees which they had already won in practice in certain countries": Simpson, The Refugee Problem, 107-108.

${ }_{98}$ Rubinstein, "The Refugee Problem", 733.
} 
Finally, to a small degree the participation of refugees in these diverse decision-making processes also contributed to the improved governance of the international refugee regime, by making decision-makers more accountable to those who had experienced the impacts of such policies. In the historical record, recognition that participation of refugees in the development of international refugee law could enhance the legitimacy of decisions is partly reflected in Robinson's remarks about the moral significance of a refugee taking the action of signing the Convention on behalf of a State. It is also tacitly acknowledged in some of the policy approaches undertaken by the League of Nations and UNHCR, such as the decision to establish field offices to more easily facilitate direct communication with refugees.

However, it is important to qualify that this governance benefit was not explicitly sought out at the time, and the refugees and persons with lived refugee experience who participated in these processes were not intended to be representative of the diverse communities of refugees in existence. While refugees from a variety of different countries of origin and countries of asylum participated in these processes, the individuals discussed in this article were able to participate due to some other type of recognised expertise (primarily legal expertise in these examples). Further, consistent with the geo-political origins of the modern international refugee regime, almost all were well-educated, European men. ${ }^{99}$ If decisionmaking processes in the future seek to be more accountable to refugees and improve governance and legitimacy in this regard, then it is important that future representation of refugees more appropriately reflects the diversity of refugee communities affected by the

\footnotetext{
${ }^{99}$ One notable exception was the participation of Toni Sender, who spoke at the Conference of Plenipotentiaries on behalf of the International Confederation of Free Trade Unions. Sender had previously served as a socialist politician in the German Weimar government, but was forced to flee Germany in 1933 due to the rise of Nazism. As one of the few female representatives at the Conference of Plenipotentiaries, she re-raised attention to the decision made by the State delegates not to include sex as one of the grounds on which discrimination was prohibited under Article 3 of the 1951 Refugee Convention. She also raised her concern about the temporal limits placed on the eligibility for refugee status, noting that "it would be both illogical and inhuman to restrict protection to the victims of past persecution" given that previously "it often took a very long time to introduce supplementary legislation, which was not infrequently passed too late to meet urgent needs". Although neither of these submissions led to changes in the final text of the 1951 Refugee Convention (the temporal limitation was removed in the 1967 Protocol), Sender's submissions nevertheless contribute to understandings of the gendered and political context in which the convention was negotiated. For Sender's submissions, see Conference of Plenipotentiaries on the Status of Refugees and Stateless Persons, Summary Records, $20^{\text {th }}$ meeting, UN doc. A/CONF.2/SR.20, 26 Nov. 1951; also, Conference of Plenipotentiaries on the Status of Refugees and Stateless Persons, Summary Records, 33 ${ }^{\text {rd }}$ meeting, UN doc. A/CONF.2/SR.33, 30 Nov. 1951. For more on Sender's political background and experience of forced displacement, see R. Critchfield, "Toni Sender: Feminist, socialist, internationalist", History of European Ideas, 15 (4-6), 1992, 701-706; also, "Toni Sender, 75, Socialist Leader: Reichstag Foe of Nazis Dies", New York Times, New York, 27 Jan.1964, 25.
} 
decisions. This includes taking into consideration consultative obligations that already exist under international law in relation to women, children and persons with disabilities. ${ }^{100}$

In contemporary international refugee law and policy, some steps have already been undertaken to address these shortcomings. For example, during the drafting of the 2018 Global Compact on Refugees, UNHCR funded a team of academics and women from diverse refugee backgrounds to undertake a "gender audit" of the Compact's legislative development. This audit aimed to ensure that issues related to gender equality, including sexual and gender-based violence and the meaningful participation of women and girls, were specifically addressed in the Compact. ${ }^{101}$ Further, there have also been other initiatives to include a broader range of refugee voices from around the world in law and policy making at the international level. These include the 2016 Global Refugee Youth Consultations, and the establishment of a Global Youth Advisory Council in 2017, to incorporate refugee youth perspectives into UNHCR's work. ${ }^{102}$ It also has involved some participation of refugees and refugee-led organisations in the inaugural Global Refugee Forum in 2019.

Nevertheless, despite initiatives such as these, more work is still needed. As refugee networks have identified, refugees face numerous barriers to meaningful participation in contemporary decision-making processes at all levels of governance. These barriers relate not only to insecure legal status and ongoing risks to personal security for many refugees, but also communication barriers, lack of financial resources, and resistance from some actors to change. ${ }^{103}$ In comparison to the examples discussed in this article, refugees today are rarely engaged as key drafters in the development of international refugee law and policy reform, and

\footnotetext{
${ }^{100}$ For more on these consultative obligations to particular groups of refugees, see Harley and Hobbs, "The Meaningful Participation of Refugees in Decision Making Processes", 209-211.

${ }^{101}$ There are sixteen different references to gender throughout the Global Compact on Refugees, including two paragraphs which specifically deal with the needs and issues facing refugee women and girls. These paragraphs include, among other things, a commitment "to promote the meaningful participation and leadership of women and girls, and to support the institutional capacity and participation of national and community-based women's organizations, as well as all relevant government ministries": see Global Compact of Refugees, paras. 74-75. For more information on the gender audit, see E. Pittaway et. al, "Gender Audits and the Global Compact on Refugees", University of New South Wales, Sydney, 2018, available at: https://www.arts.unsw.edu.au/ourresearch/research-centres-institutes/research-networks/forced-migration-research-network/projects/genderaudits-and-global-compact-refugees\# (last visited 1 Sep. 2020).

102 See UNHCR and Women's Refugee Commission, "We Believe in Youth": Global Refugee Youth Consultations, Geneva, UNHCR, Final Report, Nov. 2016, available at: https://www.unhcr.org/57e1126e7.html (last visited 1 Sep. 2020); also, C. Lenette et al, ““We Were Not Merely Participating; We Were Leading the Discussions": Participation and Self-Representation of Refugee Young People in International Advocacy", Journal of Immigrant \& Refugee Studies, 18(4), 2020, 390-404.

${ }^{103}$ Global Summit of Refugees, Policy Discussion and Outcomes Paper, 5-6; also, Asia Pacific Summit of Refugees, Outcomes Report, Bangkok, Feb. 2019, available at: https://www.globalrefugeelednetwork.org/wpcontent/uploads/2019/11/APSOR-Outcomes-Paper_Final.pdf (last visited 1 Sep. 2020) 2, 6.
} 
are rarely appointed in senior leadership roles within the primary organisations in charge of implementing protection responses. ${ }^{104}$ While some caution is needed when considering how past practices can inform the development of laws and policies that affect refugees going forward, the contributions of refugees to early international refugee law and policy demonstrate some of the benefits that arise from drawing on the considerable expertise of refugees over a sustained period, and by avoiding policy approaches that treat refugees as simply passive victims in need of rescue.

\section{CONCLUSION}

In the context of recent calls for more meaningful participation of refugees in decision-making processes that affect them, this article has sought to revisit the development of early international refugee law and policy between 1921 and 1955 and consider the contributions of refugees and persons with lived refugee experience to these developments. In doing so, the article has shifted the longstanding focus within refugee law scholarship away from how international refugee law has engaged with the subject of refugees, and instead sought to consider the opposite, namely how refugees have engaged with the subject of international refugee law. This paper has demonstrated that, contrary to widely-held assumptions, refugees and persons with lived refugee experience made a more significant contribution to the development of international refugee law and policy than has been recognised to date. These contributions included significant input into the drafting and deliberation of the 1933 Refugee Convention and the 1951 Refugee Convention, as well as substantial contributions to the policy development of international organisations, civil society organisations and refugee-led organisation during these years. These contributions not only require a reconsideration of the ways in which international law pertaining to refugees has been developed and negotiated to

\footnotetext{
${ }^{104}$ For example, since Van Heuven Goedhart, no other UN High Commissioner for Refugees has had lived experience of forced displacement. See UNHCR, Previous High Commissioners, Geneva, UNHCR, available at: https://www.unhcr.org/en-au/previous-high-commissioners.html (last visited 1 Sep. 2020).
} 
date, but they also offer a concrete case study that informs how refugees can more meaningfully participate in the formation of laws and policies that affect them going forward. 